International Conference on Porphyrin Metabolism and the Porphyrias. (1971). Proceedings. South African Medical fournal, special issue, 25 September 1971.

Mays, J. E., Jr. (1967). Acute intermittent porphyria in childhood. Oklahoma State Medical Association Fournal, 60, 240.

Monro, T. K. (1907). On haematoporphyrinuria not due to sulphonal. Quarterly fournal of Medicine, 1, 49.

Peters, H. A., Eichman, P. L., and Reese, H. H. (1958). Therapy of acute, chronic and mixed hepatic phorphyria patients with chelating agents. Neurology, 8, 621 .

Ridley, A. (1969). The neuropathy of acute intermittent porphyria. Quarterly Fournal of Medicine, 38, 307.

Ridley, A., Hierons, R., and Cavanagh, J. B. (1968). Tachycardia and the neuropathy of porphyria. Lancet, 2, 708.

Salokannel, J., and Rhen, K. (1969). Acute intermittent porphyria and pregnancy. Acta Obstetricia et Gynecologica Scandinavica, 48, 1 .

Tschudy, D. P., Perlroth, M. G., Marver, H. S., Collins, A., Hunter, G., Jr., and Rechcigl, M., Jr. (1965). Acute intermittent porphyria: the first 'overproduction disease' localized to a specific enzyme. Proceedings of the National Academy of Sciences of the U.S.A., $\mathbf{5 3}, 841$.

NAOMI BARCLAY*

Paediatric Unit, Hillingdon Hospital, Uxbridge, Middlesex.

*Correspondence to Dr. N. Barclay, c/o Professor Bankole, Faculty of Health Sciences, University of Ife, Ile-Ife, Nigeria.

\section{Acute intermittent porphyria, hypercholesterolaemia, and renal impairment}

Acute intermittent porphyria is a metabolic disorder thought to be due to deficiency of uroporphyrinogen I synthetase (Strand, Manning, and Marver, 1971). The result is the accumulation of porphobilinogen and aminolaevulinic acid. Periodic attacks of abdominal pain, vomiting, tachycardia, hypertension, neuropathy, and mental changes occur, sometimes after drugs, particularly barbiturates. The onset is very unusual before puberty and death may result from respiratory paralysis. Hypercholesterolaemia has been described, the $\beta$ - (low density) lipoprotein fraction being increased (Lees et al., 1970). Renal impairment persisting after an attack has been mentioned (Eales, Dowdle, and Sweeney, 1971), but no specific renal lesion has been described. This case presented before puberty, the hypercholesterolaemia is associated with an increase in the $\alpha$ - (high density) lipoproteins, and there is persistent impairment of renal function.

\section{Case report}

An 11-year-old girl was admitted to hospital with a history of 2 weeks of constant abdominal pain and vomiting, and 1 week of constipation and pain in the legs.
Her father was from Guyana and her mother was Caucasian. She had never received any barbiturates, sulphonamides, or tranquillizers. On examination she was dehydrated and depressed, but her abdomen and nervous system were normal. Her pulse was $120 / \mathrm{min}$ and blood pressure $140 / 110 \mathrm{mmHg}$. Her urine turned red on standing and she had a gross excess of porphobilinogen in her urine ( $40 \mathrm{mg} / 24$ hours), but no increase in urinary porphyrins or faecal porphyrins.

Her vomiting necessitated intravenous fluids for 24 hours. After 10 days she had completely recovered and was discharged home with a normal pulse, blood pressure, and plasma urea. She had 2 more similar attacks during the next 2 years. Neither of these was associated with any drug, nor had she started to menstruate. After recovery from her third attack, her plasma urea was found to be raised to between 58 and 65 $\mathrm{mg} / 100 \mathrm{ml}$. Creatinine clearance was $25 \mathrm{ml} / \mathrm{min}$ (39 $\mathrm{ml} / \mathrm{min}$ per $1.73 \mathrm{~m}^{2}$ ), serum uric acid $7.6 \mathrm{mg} / 100 \mathrm{ml}$; plasma calcium, sodium, potassium, and bicarbonate were normal. Urine contained no protein, cells, or growth, and no excess of amino acids. Overnight urinary $p \mathrm{H}$ was $5 \cdot 1$ and osmolality $600 \mathrm{mOsm} / \mathrm{l}$. Serum was negative for antinuclear factor. IVP showed normal kidneys. Blood pressure between attacks was normal and there had been no analgesic abuse.

Serum cholesterol was persistently raised at 340,320 , and $284 \mathrm{mg} / 100 \mathrm{ml}$. Serum triglyceride was normal at 90 and $60 \mathrm{mg} / 100 \mathrm{ml}$. Lipoprotein cholesterol ultracentrifugation showed an increase in the $\alpha$ - (high density) fraction at $117 \mathrm{mg} / 100 \mathrm{ml}$. The $\beta$ - (low density) fraction was at the upper limit of normal at 115 $\mathrm{mg} / 100 \mathrm{ml}$ and pre- $\beta$ - (very low density) fraction was normal at $23 \mathrm{mg} / 100 \mathrm{ml}$. She had additional abnormalities of plasma proteins. Albumin was normal at $4 \cdot 2 \mathrm{~g} / 100 \mathrm{ml}$, but globulin was raised at $4 \cdot 2 \mathrm{~g} / 100 \mathrm{ml}$, the increase being in the $\gamma$-fraction, IgG $2 \mathrm{~g} / 100 \mathrm{ml}$ (raised), IgM $0.315 \mathrm{~g} / 100 \mathrm{ml}$ (raised), IgA normal. Excess of thyroxine-binding globulin was indicated by finding serum $\mathrm{T}_{3}$ resin uptake in the hypothyroid range, while all other thyroid function tests, serum $T_{4}$, free thyroxine index, and radio-iodine uptake were normal.

She remains asymptomatic and carries a card warning against the administration of the numerous drugs which may precipitate another attack.

\section{Discussion}

The patient had typical symptoms and signs of acute intermittent porphyria. The diagnosis was confirmed by the excess of porphobilinogen in the urine without porphyrins in the urine or faeces. She is unusual in presenting before puberty and in having no family history. Neither parent nor any of the sibs has porphobilinogen in the urine and we must assume that this patient is a new mutation.

In a large series of patients with porphyria, Eales et al. (1971) found a decreased creatinine clearance during acute attacks. In most patients this could be explained by dehydration and in only a very few 
patients did the impairment persist. In a series of necropsies on patients with porphyria in South Africa, about $80 \%$ had renal tubular necrosis histologically (Eales et al., 1971). Most of these patients died of respiratory failure and the tubular necrosis may have resulted from hypoxia. Investigation in this patient has failed to suggest any of the common renal diseases and it may be that one of the accumulated compounds is nephrotoxic.

Lees et al. (1970) found raised plasma cholesterol values in 5 out of 10 patients with acute intermittent porphyria. Plasma triglycerides were normal, as were the very low density and high density lipoproteins. However, the low density $(\beta-)$ lipoproteins were increased in 9 out of 10 patients. There have been no reports to date of raised $\alpha$-(high density) lipoprotein in acute intermittent porphyria, though this fraction is sometimes increased by oestrogen administration (Rifkind, 1970). This patient also had increased thyroxine-binding globulin which has been previously reported in porphyria and also in oestrogen administration (Brownlie, 1973). There may be increased synthesis of a number of different proteins in porphyria. It is of interest that oestrogens can also precipitate attacks of acute intermittent porphyria.

This patient is reported because renal damage is an unusual and unexplained complication of acute intermittent porphyria and because increased high density lipoproteins have not been previously reported in this condition.

\section{Summary}

An 11-year-old girl presented with typical clinical and biochemical findings of acute intermittent porphyria. After recovery from her third attack, she was found to have persistently raised serum cholesterol and high density $(\alpha-)$ lipoproteins. Her creatinine clearance was persistently reduced to below $40 \%$ of normal. Possible interpretations are discussed.

I am grateful to Professor T. E. Oppé and Drs. P. Adams and $G$. Tait for their help in the investigation of this patient.

\section{REFERENCES}

Brownlie, B. E. W. (1973). Interpretation of thyroid function tests. Modern Medicine, 18, 427.

Eales, L., Dowdle, E. B., and Sweeney, G. D. (1971). The acute porphyric attack. I. The electrolyte disorder of the acute porphyric attack and the possible role of delta-aminolaevulic acid. South African Medical Fournal, (Special issue) 25 September $1971,89$.

Lees, R. S., Song, C. S., Levere, R. D., and Kappas, A. (1970). Hyperbeta-lipoproteinemia in acute intermittent porphyria. New England fournal of Medicine, 282, 432.

Rifkind, B. M. (1970). The hyperlipoproteinaemias. British fournal of Hospital Medicine, 4, 683.
Strand, L. J., Manning, J., and Marver, H. S. (1971). Acute intermittent porphyria: studies of the enzymatic basis of disordered haem biosynthesis. South African Medical fournal, (Special issue) 25 September $1971,108$.

A. G. L. WhitelaW

Paediatric Unit, St. Mary's Hospital, London.

*Correspondence to A.G.L.W., The Hospital for Sick Children, Great Ormorf Street, London WC1N 3JH.

\section{Hydrocephalus related to pulsion diverticulum of lateral ventricle}

The clinical syndrome of headache and vomiting together with signs of raised intracranial pressure is known to be associated in paediatrics with a variety of causes, both benign and malignant. We describe below a rare and interesting cause which we have not seen previously reported in children.

\section{Case report}

A 6-year-old boy had been seen in outpatients a year before his emergency admission in November 1972 with persistent episodic headaches for 2 to 3 years, thought to be associated with upper respiratory tract infections. One severe attack had lasted a week and had been associated with vomiting. His mother had typical attacks of migraine. On examination nothing abnormal was found and his parents were reassured.

When admitted, his attacks of headache and vomiting were said to have steadily increased in frequency and severity and he had become irritable. In the preceding 6 months he had had three particularly bad attacks in which he had woken complaining of headache which had increased in severity for about half an hour and was associated with nausea followed by vomiting which would temporarily alleviate the headache. During these attacks he was noticeably drowsy. One attack lasted for a week and during this time he had resented normal noises and shown an intense dislike for the smell of food. His mother and teacher had noticed no unsteadiness, but he had apparently developed a tendency to fall over.

Past history was noncontributory. Antenatal and neonatal progress were uneventful and his general health was excellent. The paternal grandmother had recently died of a cerebral tumour, and this had clearly contributed to the parents' anxiety.

On examination he was fully conscious and alert, and no abnormalities were detected outside the nervous system. There was a definite cracked pot sound on percussion of his skull, though there was no clinically obvious hydrocephalus. There was minimal neck stiffness and Kernig's sign was negative. Cranial nerves were intact. Visual fields were full. Fundoscopy showed no papilloedema. His eye movements and gaze co-ordination were normal. There was no nystagmus. Power, tone, reflexes, and sensation were all normal.

Skull $x$-ray showed definite evidence of raised 